\title{
Writer's Voice: The Gateway to Dialogue
}

\section{CATHI SHAW}

University of British Columbia Okanagan,

Writer's voice is a term that is used almost universally in composition instruction. Despite the widespread use of the term, there is no consensus amongst scholars with respect to a standard definition of the term. This paper offers a new conceptualization of voice with a focus on academic literacy and student writers. Through a merging of Vygotsky's theory of Inner Speech and External Thought with Bakbtin's concept of the Utterance a definition of writer's voice is proposed that honors both meaning-making and text production in academic discourse.

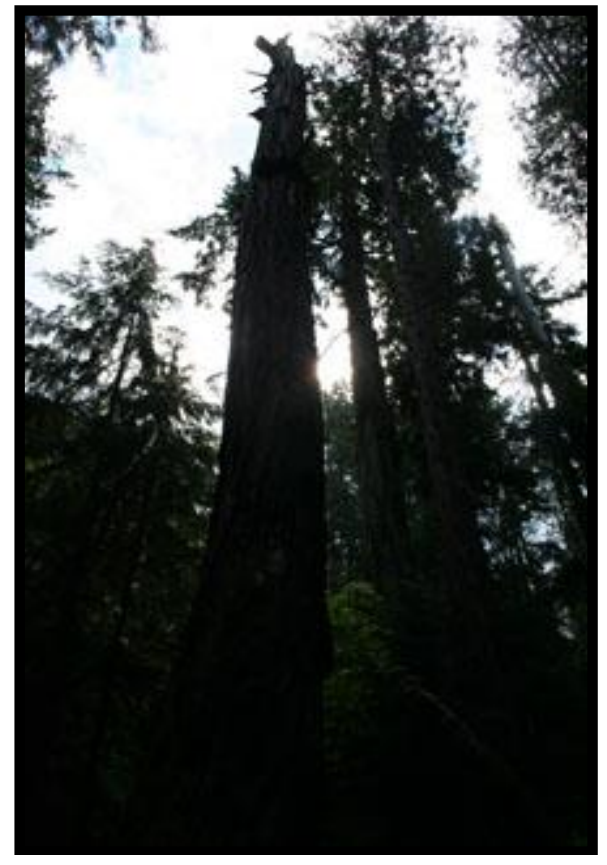

Consciousness is reflected in a word as the sun in a drop of water.

Lev Vygotsky (1986, p. 256)

Our speech, that is, all our utterances (including creative works), is filled with others' words, varying degrees of otherness or varying degrees of "our-own-ness," varying degrees of awareness and detachment. These words of others carry with them their own expression, their own evaluative tone, which we assimilate, rework and re-accentuate."

Mikhail Bakhtin (1986, p. 89)

(C) Copyright 2010. The author, Cathi Shaw, assigns to the SFU Educational Review the right of first publication and educational and non-profit institutions a non-exclusive license to use this document for personal use and in courses of instruction provided that the article is used in full and this copyright statement is reproduced. Any other usage is probibited without the express permission of the author. 
Voice in writing. All writing instructors I know use the term. But what do we mean by voice in writing?

A quick review of the myriad of Canadian composition textbooks that exist reveals the importance of something called voice in student writing. A closer look reveals that the term voice is rarely defined. There appears to be an assumption that there is a universal meaning behind the term but I think we need to look closely at precisely what we mean when we identify voice in writing, particularly when we are trying to develop voice in our students.

The expressivist literary theorists from America all give similar but fundamentally different definitions of voice. For example, Donald Murray (2004b) argues that there is no one voice we use in writing. He notes that students arrive in the classroom with many voices and that they must learn which voice is appropriate for which situation (p. 205). Peter Elbow (2000), on the other hand, likens the development of writer's voice as learning to sing in different pitches. Before we can become proficient with all notes we must first become comfortable with our own pitch (p. 282). Tom Romano (2004) calls voice "... the writer's presence on the page" (p. 5).

While these different definitions of writer's voice are intriguing, I am proposing a different understanding of writer's voice; one that encompasses both the inner self and the external sociohistorical influences through which writers must work. This understanding of writer's voice is shaped by the theories of Lev Vygotsky and Mikhail Bakhtin.

\section{The Development of Inner Voice: Lev Vygotsky}

Lev Vygotsky's theory of verbal thought and inner speech plays a significant role in understanding the concept of writer's voice. While verbal speech differs considerably from the concept of written voice, there are a number of parallels between the two. Vygotsky's verbal thought theory is characterized by the intersection of thought and speech that defines the beginnings of writer's voice in composition.

\section{Thought and Voice}

Vygotsky (1986) speaks of the junction between thought and speech as two intersecting circles (See Figure 1). He calls the overlapping area between thought and speech verbal thought (p. 88). This intersecting area in/between thought and speech is integral to the development of voice in writing.

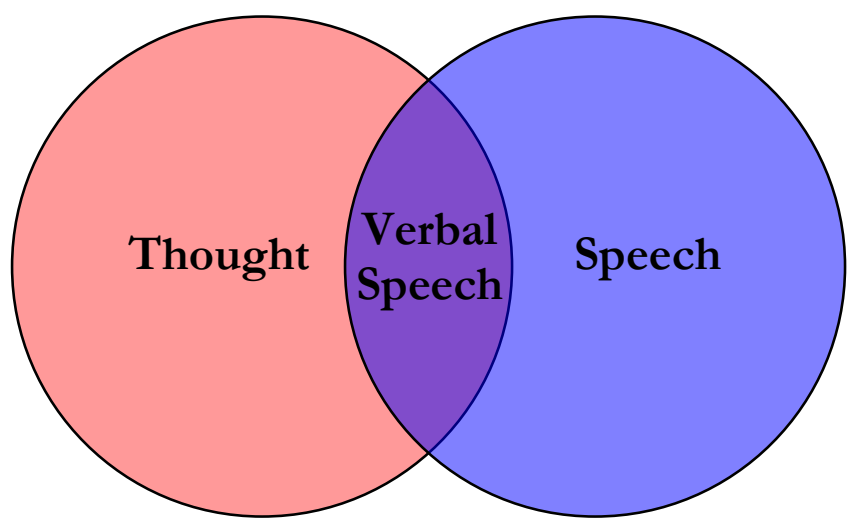

Figure 1: Vygotsky's Conceptualization of Thought/Speech 
At first it is difficult to envision either thought or speech occurring without the other. However, according to Vygotsky, verbal thought takes place in the intersecting area between thought and speech; it encompasses neither all thought nor all speech. He claims that both thought and speech each occur at times without the other.

This idea seems most reasonable when one thinks of thought without speech. We all have moments of thought that are not accompanied by speech; in fact, one could argue that a better part of any human's time is spent thinking without necessarily verbalizing that thought. This seems to be an elementary notion. However, it becomes more difficult to envision speech without thought. How can speech happen without conscious thought?

Vygotsky provides several convincing examples of when speech occurs without thought: for example, when one recites something he/she has memorized without consciously thinking of what is being spoken such as a memorized poem or a sentence. He also suggests that lyrical speech, or speech prompted by emotion, occurs separately from intellectual activity (Vygotsky, 1986).

The example of lyrical speech is an important one for writing instruction, particularly when one employs personal narrative in the classroom. Personal narrative is often heavily imbued with something very similar to lyrical speech - it could be argued that in certain kinds of discourse, the writer produces a piece that is purely emotional. This emphasis on a kind of lyrical speech in narrative writing can be identified as one of the contributing factors to the pedagogical debate about using narrative in the composition classroom.

However, while a kind of lyrical speech can dominate narrative writing, a purely lyrical form is not what most writing instructors are striving for when they use narrative as a pedagogical tool in the academic writing classroom. Instead, it is the kind of narrative that is composed from the place of verbal thought that writing instructors are striving to move their students' writing toward.. I am suggesting that verbal thought, the intersection between speech and thought where inner speech overlaps external speech, is the space from which we wish our students to produce the voice in their writing (See Figure 2). This voice reflects both the students' inner speech and the thoughts they wish to express through their writing.

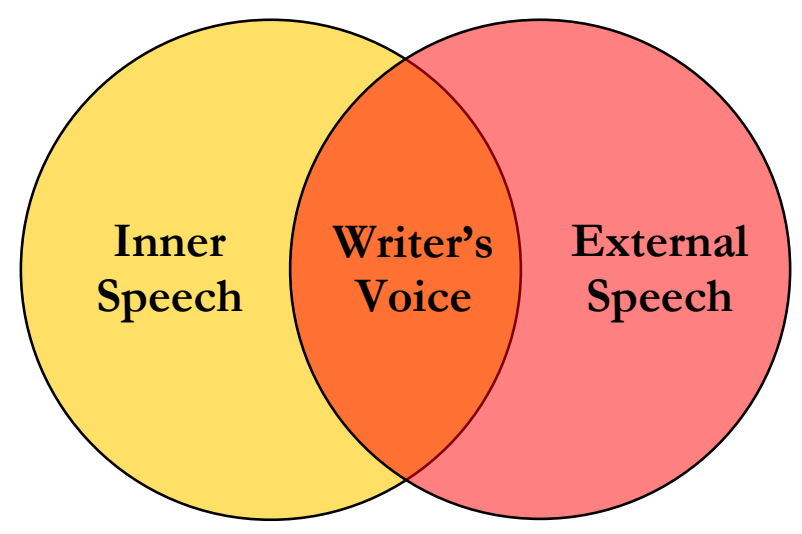

Figure 2: Writer's Voice: The Intersection between Inner Speech and External Speech Inner Speech and External Speech

For Vygotsky (1986), inner speech could be defined on an elementary level as "speech for oneself" while "external speech is speech for others" (p. 225). However, Vygotsky goes beyond this simple explanation to argued that, in fact, inner speech and external speech are binary opposites.

External speech is the process of turning thoughts into words. We can see the relation to writing, as our students take their thoughts and turn them into words on paper. With external speech there is always the element of audience present. 
On the other hand, Vygotsky (1986) saw inner speech as the reversal of external speech - "overt speech sublimates into thoughts" (p. 226). Vygotsky studied the nature of inner speech through children's egocentric speech or the kind of verbal speech in which children engage when they are playing on their own. Egocentric speech usually sounds as gibberish to an onlooker; the child is typically not aware of an audience. His theory was that children's egocentric speech is a predecessor to the development of internal speech, as egocentric speech disappears at school age. He concluded that this transition from egocentric speech to internal speech represented the child's "gradual individualization" (p. 228).

Inner speech is only meaningful to the person who hears it (i.e., the individual for whom the inner speech is occurring). To all others, inner speech "appears disconnected and incomplete" (p. 235). In writing, inner speech can never translate to paper because the writer is always cognisant of his/her audience - even in private writing such as diary or journal entries there is a perceived audience. One is always writing for someone even if that someone is a future version of oneself so inner speech can rarely be articulated in its pure form; nevertheless, it plays an important role in writing. According to Vygotsky, inner speech is particularly evident in the process of drafting a piece of writing. Even those students who do not write down a draft engage in an inner planning process - and this internal draft is inner speech.

Often one of the most difficult concepts to teach students is that writing a draft of their work is essential. The draft is the gateway to the final product and if we focus on Vygotsky's belief that inner speech equates the draft, student hesitation over the process is understandable. Attempting to write inner speech down or externalize it can be an uncomfortable process; the process of transforming our inner speech into something external is never going to result in a perfect product because inner speech cannot be verbalized. Instead, the goal should be to capture the essence of inner speech. Rather than working through this process, students often try to expropriate external authoritarian speech into their academic writing, leaving inner speech behind altogether. Vygotsky suggests this happens due to the dissatisfaction between the translation of thought into speech, or internal speech into external speech.

Perhaps the most pertinent point Vygotsky (1986) makes to the teaching of writing is the fact that "to understand another's speech, it is not sufficient to understand his words - we must understand his thought. But even that is not enough - we must also know its motivation" (p. 253). It seems to me that the quintessence of this statement is that we need to come to see one another as human beings, with all our differences and commonalities. Successful communication requires an opening to the other, a willingness to listen and express in an effort to come to a space of understanding. This in/between space where our words meet the words of another is the key to understanding. Vygotsky (1986) describes this relationship between thought and words as a "living process" (p. 255). And as a living process it is constantly changing and evolving.

\section{The Bakhtian Utterance}

For another Russian philosopher, Mikhail Bakhtin (1986), speech is always a culmination of many voices. Each "utterance is individual"; however, each utterance is also influenced by the socio-historical voices that have both come before and that are yet to come (p. 63). The voices could be said to live within the language that we use. I believe that Bakhtin's utterance correlates with Vygotsky's verbal thought and hence to writer's voice; however, Bakhtin's theory brings to this discussion a sociohistorical element.

Bakhtin (1986) speaks of "primary" and "secondary speech genres" (p. 62), both of which can be defined as "typical forms of utterances" (p. 63). Primary speech genres are realized through "unmediated speech communion" (p. 62); dialogue within the classroom or between students, for instance. Secondary speech genres are created out of primary speech genres. However, Bakhtin (1986) argues that as primary speech genres are transformed they "lose their immediate relation to actual 
reality and to the real utterances of others" (p. 62). Academic written language would be an example of a secondary speech genre.

The utterance, according to Bakhtin (1986), is always "individual and therefore can reflect the individuality of the speaker (or writer)" (p. 63, emphasis added). I think that can in this quote is important because, as Bakhtin himself notes, speech genres have varying degrees of room for individuality (for example, an artistic utterance, such as a poem or novel, will have more room for individuality than a standardized form of writing, such as a business letter). For Bakhtin there is an irrevocable link between individual style and genre. Therefore, the best form of academic essay, I argue, falls between the artistic utterance and standardized writing or in the in/between space.

To restate Bakhtin's terminology, we have primary and secondary speech genres, which are made up of different utterances but the utterance should not be equated to a word. The utterance is more than a word or sentence. It is the thought that is contained within the utterance. Here is the link between Vygotsky's verbal thought and the utterance.

Bakhtin's emphasis on the socio-historical influences of the utterance makes his concept of the utterance different than Vygotsky's notion of verbal thought. Bakhtin decries the tendency to look at language solely from the view of the speaker. All language includes both a speaker and an audience, usually more than one. In composition studies, the speaker is the writer and as a writer she is engaging in a timeless dialogue with all those utterances that have come before her. The writer is not usually consciously aware of this fact. Bakhtin insists that any utterance exists in a continuum of utterances those that have come before and those that will come after. For writing students, it is important to understand that their inner speech is a kind of utterance and as such is related to all those utterances that have come before and also to those that will come after. Bakhtin called the dynamic fusion of languages within one language heteroglossia. This heteroglossia of voices exists wherever the utterance takes shape.

The idea that we are in a never-ending conversation with humanity can be both exciting and threatening. To acknowledge that the utterances that make up one's written work are not as uniquely one's own strains against the individualistic ideology that defines so much of our existence in the $21^{\text {st }}$ century. And at the same time it can be oddly comforting to believe that we are not alone, we are just a single drop in the bottomless bucket, contributing but not in isolation.

Of particular use to the writing student is Bakhtin's (1986) observation that "a practical command of the generic forms in [a] given sphere" is needed to ensure successful communication (p. 80). Bakhtin says that competence in one sphere of writing does not necessarily translate to competence in another. So, if we look at the example of academic literacy, students who are perfectly comfortable writing in narrative style may struggle with successful academic communication because they have yet to master the genres used in the academic realm.

As Bakhtin (1986) observes, it is in "the genre" that a word "acquires a particular typical expression" (p. 87). One of the struggles that weak academic writers encounter, particularly L2 learners, is that fact that utterances are not created based on "their neutral, dictionary form" - instead they are constructed from "other utterances" in that particular genre (p. 87, emphasis in original). Hence, a beginning academic writer will write an utterance that makes perfect sense by definition but has the incorrect expression in that particular speech genre.

It is important for writing students to understand that the words they choose are both contextual and individual in nature. That is, the word exists in three different forms, all at once: 1) in the dictionary sense: as a neutral word; 2) as someone else's word, filled with their utterance; 3) as "my word" - used in the context of my utterance (p. 88). These interconnected forms are difficult to conceptualize when one approaches language from a literal and linear stance.

The utterance is the basis for dialogue. Bakhtin wrote that absolutes do not exists - debate is necessary. Bakhtin believed there is no ultimate end or goal to true dialogue. Dialogue itself, is the goal. Writing is one form in which this ongoing dialogue takes place. This is particularly true for academic writing where the writer is engaging in a dialogic conversation with previous authors and with the 
future reader so the writing itself lives in an in/between space. For example, in this article my own writing is the gateway for an ongoing dialogue between myself, as the writer, yourself, as the reader and those who have come before: Bakhtin, Vygotsky and others. This spiral of ongoing dialogue can be illustrated even further when we consider that these writers who have come before were also in dialogue with both their audience and those who came before them. And you, the reader, may extend this dialogue even further. In this way, the heteroglossia of voices lives within our writing.

Carolyn Shields (2007) says that for Bakhtin “... living in openness to others is life in its fullness; it permits us to make choices; to take positions; to act - in the fullness of our (albeit temporary) understandings of who we are" (p. 78). Living dialogically is a never-ending process. You don't ever finish - it is ongoing and dynamic. This philosophical approach is difficult to accept in our instrumental, goal oriented society where we are accustomed to valuing the end product of our endeavors. This is particularly evident when we think of writing, for most of us are exposed only to the published end results of any one piece of writing; the reality of writing is more about process than product. Applying Bakhtin's dialogic approach to writing, we are faced with the reality that there is no end product - the writing will continue to evolve as an utterance in communion with other, equally evolving utterances. But the concept of writing as a form of dialogue is often a difficult one for students to grasp. Beginning academic writers often see their writing as being generated for someone else (usually the instructor) but they fail to see it as the beginning of a dialogue.

Returning to Vygotsky's concept of verbal thought, I would like to suggest that Bakhtin's utterance is another conceptualization of writers' voice; however, Bakhtin moves away from the individual voice (although that is always present) and speaks of the utterances encompassing a heteroglossia of voices (See Figure 3).

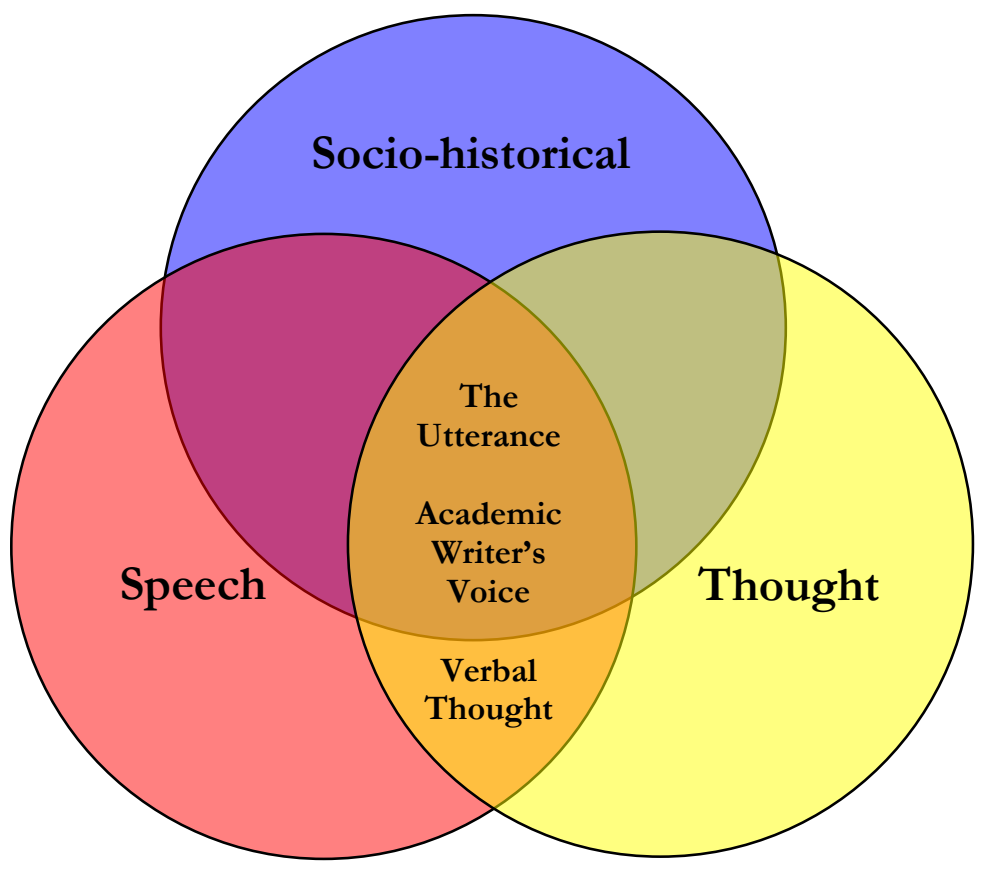

Figure 3: Vygotsky \& Bakhtin and Writer's Voice

In this way, writer's voice in the Academy becomes a gateway to dialogue. Thus, while verbal thought is characterized by the union of two individual concepts (speech and thought), the utterance brings in the third dynamic and ever-changing socio-historical element, which ensures that writer's 
voice is a changing organic phenomenon. With Bakhtin's philosophy informing the conceptual framework of writer's voice above, it becomes richer and moves away from the individualistic tendencies inherent in verbal thought alone.

\section{Dialogical Understanding: The Self in Academic Writing}

The pedagogical practice of using personal narrative in composition studies has sparked much debate. Both Donald Murray and Peter Elbow have been labelled as expressionist composition theorists because of their emphasis on the self in the writing process (DeBlase, 2002). The argument against the studentcentred pedagogy employed by Murray and Elbow revolves around the position that teaching students to write personal narrative does not prepare them for academic discourse (Bishop, 1999).

In an article entitled "What is Voice in Writing?" Peter Elbow (2000) contends that there is an either/or debate with respect to teaching beginning writers, which focuses on "writing as the production of text" versus the emphasis of the development of voice in writing. Rather than seeing these as dichotomous, Elbow argues that they can take place simultaneously.

Text production and voice development can (and do) take place concurrently. To achieve verbal speech, thought must intersect with inner speech (narrative). Human thought is a systematic phenomenon; part of text production naturally occurs from thought. However, text production is also influenced by socio-historical elements - all those utterances that have been produced and are being produced in society. And so text production takes place in the intersection between the spheres of Vygotsky's thought and Bakhtin's socio-historical space.

Inner speech also intersects with the socio-historical (albeit at times unconsciously); this is where meaning making takes place for the individual in inner speech (although it may not make meaning to others). The socio-historical perspective always informs our conceptualization of reality.

It is the overlapping areas between text production and meaning making where writers' voice can emerge. (See Figure 4). 


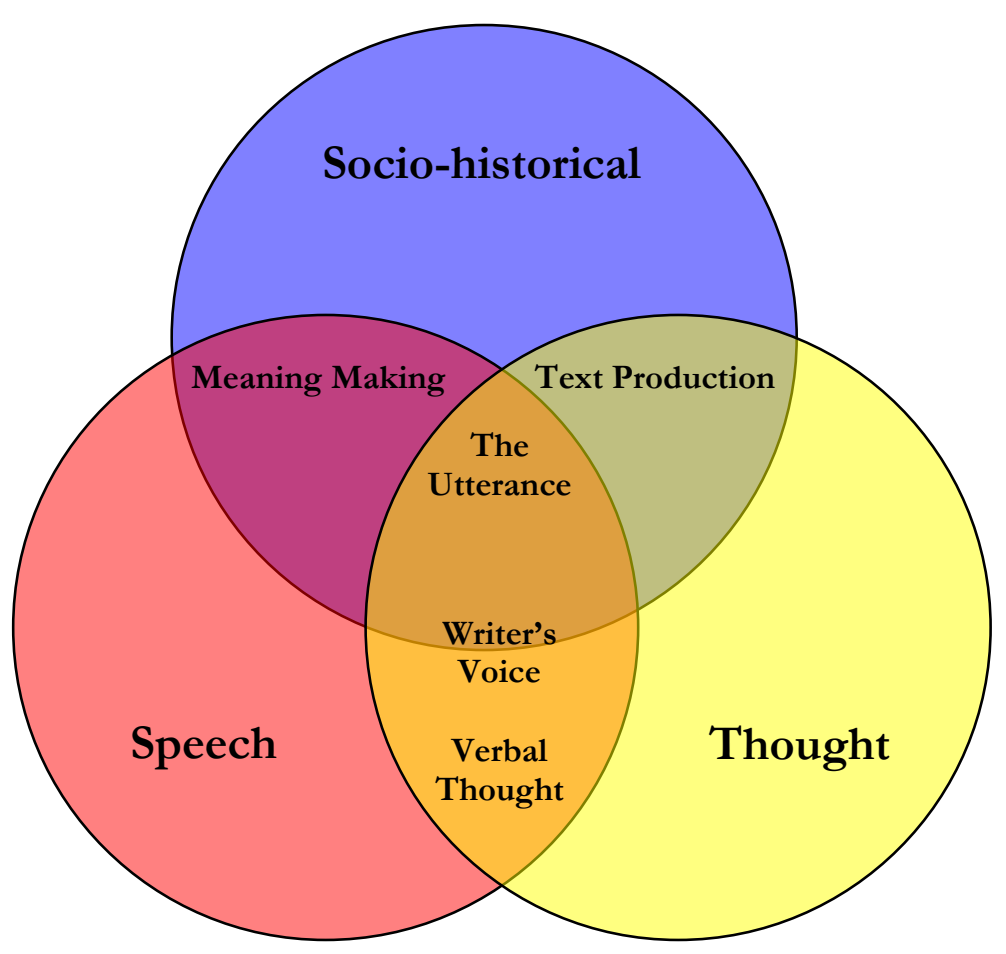

Figure 4: Meaning-Making and Text Production $=$ Writer's Voice

Rather than seeing text-production and meaning making as dichotomous, they are complementary and reliant upon one another. The academic writer's voice that we are striving to encourage in our composition students is neither wholly focused on text-production nor narrative but is a blending of the two. From the space where speech, thought and the socio-historical intersect emerges the possibility for the development of a writer's voice that is valued in academic settings. This voice cannot be developed by focusing on either narrative or text production alone. Pedagogically both text-production and narrative writing must be seen as part of the process of developing academic writer's voice in our students.

\section{Student Voice in University Discourse}

Hirvela and Belcher (2001) have argued that students do not arrive at the university without a voice. They suggest that students already have a well-developed inner voice but may need assistance in molding that voice to the academic setting. Other studies have shown that successful students tend to conform to discourse that is valued in the university setting even if that means surrendering their own voice in the process; this surrender usually happens within the first year of study (Bangeni \& Kapp, 2006). However, appropriation of an acceptable voice, rather than learning to develop their own writer's voice results in students who are unable to articulate their own critical interpretation of the world around them.

On the other hand, students who are given the space to tell their own stories in the academic setting are more likely to feel they belong and have a place in the Academy (Creme, 2000). From this place of belonging, students are then more likely to be contributing members of the academic community. 
As teachers of writing it is important for us to understand the various forces that influence the development of writer's voice. As our students struggle to make sense of academic writing they often abandon their natural voice for an appropriated academic voice. The result is often a flat and incomplete tone in the student writing. On the other hand, the best student writers are the ones that know precisely how to write and speak in the university setting that at once preserves their individuality and at the same time identifies them as members of the academic community. The challenge for instructors in the composition classroom is to create a space that allows students to transfer their inner speech into an external voice in dialogue with the other voices that encircle them in the academic setting.

\section{Acknowledgments}

The author would like to thank to Dr. Carolyn Mamchur and the instructors and students of the FAL course, who shared their stories and wisdom so generously.

\section{References}

Bakhtin, M.M. (1986). Speech genres and other late essays. Austin, TX: University of Texas Press.

Bangeni, B \& Kapp, R. (2006). 'I want to write about the Dalai Lama ...': Literacies in transition. In L. Thesen \& E. van Pletzen (Eds.), Academic Literacy and the Languages of Change (pp. 67-83). New York: Continuum.

Bishop, W. (1999). Places to stand: The reflective writer-teacher-writer in composition. College Composition and Communication, 51(1), 9-31.

Creme, P. (2000). The personal in university writing: Uses of reflective learning journals. In M.R. Lea \& B. Stierer (Eds.), Student writing in higher education: New contexts (pp. 97-111). Philadelphia, PA: SRHE \& Open University Press.

De Blase, G. (2002). Discourse in the composition classroom: Agency, personal narrative and the politics of disclosure. Teaching English in the Two-Year College (TETYC), 29(4), 367-379.

Elbow, P. (2000). Everyone can write. Essays towards a hopeful theory of writing and teaching writing. New York: Oxford University Press.

Hirvela, A. \& Belcher, D. (2007). Writing scholars as teacher educators: Exploring writing teacher education. Journal of Second Language Writing, 16, 125-128.

Murray, D (2004b). The craft of revision. Boston: Thomson Wadsworth.

Romano, T. (2004). Crafting authentic voice. Portsmouth, NH: Heinemann.

Shields, C.M (2007). Bakbtin. New York: Peter Lang.

Vygotsky, L.S. (1986). Thought and language. Cambridge: The MIT Press.

\section{About the Author}

Cathi Shaw is an instructor and adjunct professor at the University of British Columbia, Okanagan where she teaches academic and professional writing. She completed her $\mathrm{PhD}$ at Simon Fraser University in 2009. Her doctoral dissertation focused on the development of voice in academic writing. She has taught writing at Simon Fraser University, Okanagan College and UBCOkanagan. Cathi incorporates poetic and narrative inquiry into her academic research through the use of photography, personal narrative and poetry. 